\title{
Application of modified simplex on the development of a preconcentration system for cadmium determination in sediments, food and cigarettes
}

\author{
QUEILA O. SANTOS, ISLANIA MORENO, LEANDRO DOS SANTOS, ALDENOR \\ G. SANTOS, VALDINEI S. SOUZA and MARCOS A. BEZERRA \\ Laboratório de Química Analítica (LQA), Núcleo de Química Analítica da Bahia (NQA), Universidade Estadual \\ do Sudoeste da Bahia, Campus de Jequié, Rua José Moreira Sobrinho, s/n, 45506-191 Jequié, BA, Brasil
}

Manuscript received on March 30, 2015; accepted for publication on June 2, 2015

\begin{abstract}
A modified simplex algorithm was used to optimize a system of preconcentration for cadmium determination in samples of sediments, cigarettes and food using flame atomic absorption spectrometry. The preconcentration system is based on the sorption of cadmium in a minicolumn packed with Amberlite XAD-2 resin functionalized with 3,4-dihydroxybenzoic acid (DHB). The optimized variables were $\mathrm{pH}$ and sampling flow rate and the optimum conditions found for these variables were, respectively 8.7 and 8.8 $\mathrm{mL} \min ^{-1}$. The developed system showed a preconcentration factor of 15.3 , detection limit of $0.49 \mu \mathrm{g} \mathrm{L}^{-1}$, quantification limit of $1.65 \mu \mathrm{g} \mathrm{L}^{-1}$ and precision expressed as relative standard deviation (\% RSD, $\mathrm{n}=10$ ) of 5.9. The accuracy of the method was checked by analysis of estuary sediment certified reference material (NIST 1646-1). The cadmium concentrations found in sediment samples ranged from 1.73 and $1.90 \mu \mathrm{g} \mathrm{g}^{-1}$. In cigarette samples the results were 0.085 and $0.193 \mu \mathrm{g} \mathrm{g}^{-1}$, and in food samples (coriander and lettuce) the concentrations found of this metal were, respectively, 0.33 and $0.12 \mu \mathrm{g} \mathrm{g}^{-1}$.
\end{abstract}

Key words: simplex optimization, preconcentration, cadmium, sediments, cigarettes, food.

\section{INTRODUCTION}

Cadmium is a metal without any known biological function, and exposure to high levels of this metal can lead to several health hazards in humans, including cancer (Ojeda et al. 2010). The main source of human exposure to this metal is through contaminated food and cigarettes, thus, the importance of cadmium determination in these samples (Lemos and Carvalho 2010). Knowing the amount of cadmium in sediments is also of fundamental importance to determine the level of

Correspondence to: Queila Oliveira dos Santos

E-mail: qosquimica@hotmail.com pollution of water effluents, since the sediments are able to retain heavy metals (Giesy and Hoke 1989).

Among the atomic spectrometric techniques, FAAS has been very attractive for $\mathrm{Cd}$ quantification in various matrixes because of its characteristics, such as operational facility and low cost, especially when compared to GFAAS and ICP OES techniques (Silva and Roldan 2009), and also high selectivity, equipment's robustness and analysis speed (Rodrigues et al. 2011). Cadmium determination by this technique is also virtually free of spectral interferences and this metal can be easily atomized in air-acetylene flame (Ferreira 
et al. 2007). However, this technique has the disadvantage of not having a limit of detection low enough to allow direct cadmium determination in trace quantities in various matrices. Thus, it is necessary to use preconcentration procedures to enable cadmium determination by FAAS. Several cadmium preconcentration procedures have been described in the literature, such as electrochemical deposition (Abdullin et al. 2000), precipitation and coprecipitation (Döner and Ege 2005), liquidliquid extraction (LLE) (Amorim and Ferreira 2005), cloud point extraction (CPE) (Escaleira et al. 2009) and solid-phase extraction (SFE) (Lemos et al. 2008). The latter has been widely used for quantification of cadmium ions in various samples, such as food (Julshamn et al. 2008), natural waters (Anthemidis and Ioannou 2010), animal tissues (Shokrollahi et al. 2011), urine (Shokrollahi et al. 2013), antibiotics (Paula et al. 2012) and sediments (Dias et al. 2005), among others, because it provides advantages such as low cost, achievement of high recoveries and easy recovery of the solid-phase, simplicity and high preconcentration factor (Camel 2003, Lemos et al. 2006, Novaes et al. 2010).

The simplex optimization method is characterized by easy application and by the mathematical simplicity of its algorithms. A simplex is a spatial configuration of $n$ dimensions determined by $n+1$ points in a space of dimension equal to or greater than $\mathrm{n}$ (Neto et al. 1995). The modified simplex method (MSM) has been developed by Nelder and Mead (1965) from the basic simplex method. The modified simplex can change its size and shape (unlike the basic simplex method), adjusting better to the response surface describing the experimental region studied, and consequently enables a more accurate determination of the optimum point, since the simplex size can decrease in its vicinity (Neto et al. 1995).

In this study, it was used a modified simplex algorithm for the optimization of a preconcentration system for cadmium determination by flame atomic absorption spectrometry. The preconcentration is based on solid-phase extraction of the analyte in a minicolumn packed with Amberlite XAD-2 resin functionalized with 3,4-dihydroxybenzoic acid (DHB). In this work, modified simplex was chosen instead of other multivariate optimization method (such as factorial or response surface methodology) because it is based on very simple mathematical treatment, is easily and efficiently applied in the optimization of systems that generate rapid responses such as the flow analysis systems.

\section{EXPERIMENTAL PART}

\section{INSTRUMENTATION}

Absorbance measurements were performed using an atomic absorption spectrometer Perkin Elmer model AAnalyst 200, equiped with a deuterium lamp as background correction. It was used a cadmium hollow cathode lamp as source of radiation and an air-acetylene flame. The conditions used in the spectrometer operation were as follows: 288.8 $\mathrm{nm}$ wavelength, $15 \mathrm{~mA}$ current and lamp slit width of $0.5 \mathrm{~nm}$. The flow rates of acetylene, air and nebulizer were, respectively, 2.0, 13.5 and $5.0 \mathrm{~mL}$ $\min ^{-1}$

A Digimed DM 20 (Santo Amaro, Brazil) $\mathrm{pH}$ meter was used for monitoring the $\mathrm{pH}$ of the solutions. Sample digestion was carried out by using digester block with 40 coupled sample tubes (QUIMIS, Brazil). The schematic diagram of the preconcentration system used is illustrated in Figure 1, showing the three process steps, which are: preconcentration, elution and detection, respectively. The system consists of a multichannel peristaltic pump (Milan, Colombo, Brazil) coupled to minicolumn packed with Amberlite XAD-2 resin functionalized with 3,4-dihydroxybenzoic acid (DHB), silicone tubing and connections.

\section{REAGENTS AND SOLUTIONS}

Deionized water was used to prepare all solutions. The glassware was maintained in a $10 \% \mathrm{v} / \mathrm{v}$ nitric 


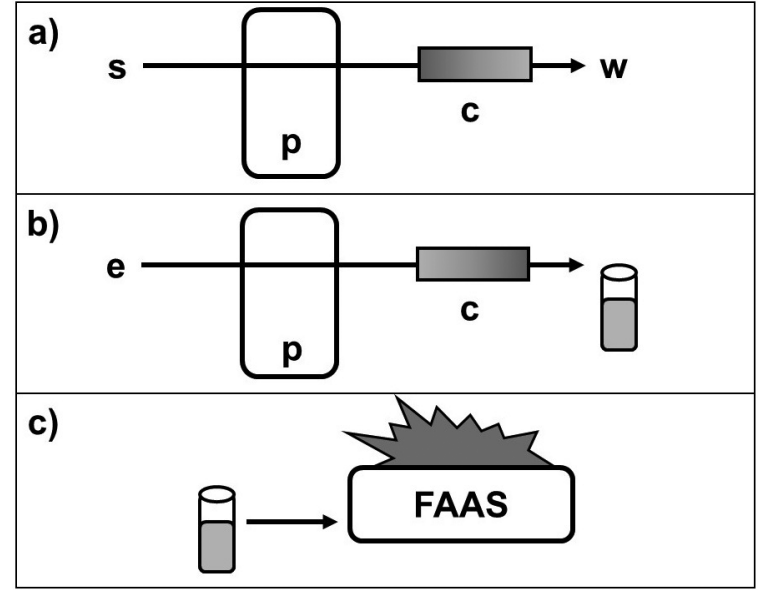

Figure 1 - Diagram of the preconcentration procedure used for determination of cadmium by FAAS. s. sample; e. Eluent; p. Peristaltic pump; c. AT-XAD-2 minicolumn; W. waste. (a) preconcentration stage, (b) elution stage, (c) stage of metal determination.

acid solution overnight before use to remove metal residues. All used reagents were of analytical grade. The cadmium working solutions were prepared daily by dilution of the metal stock solution 1000 $\mu \mathrm{g} \mathrm{L}^{-1}$ (Merck, Darmstadt, Germany) in deionized water. Hydrochloric and nitric acid solutions were prepared by direct dilution of the concentrated solutions (Merck) in deionized water. Acetate buffer solutions ( $\mathrm{pH} 3.8$ to 5.8), borate ( $\mathrm{pH} 7.5$ to 9.0) and ammonia (pH 9.0 to 10.0) were used to adjust the $\mathrm{pH}$ of the cadmium solutions. Amberlite $\mathrm{XAD}-2, \mathrm{NaOH}$ and $\mathrm{SnCl}_{2}$ were purchased from Acros Organics.

SYNTHESIS OF DHB-XAD-2 RESIN AND MINICOLUMN PREPARATION

Procedures described in the literature for similar reagents have been used for the XAD-DHB synthesis (Lemos et al. 2003). Approximately $5.0 \mathrm{~g}$ XAD-2 resin was treated with $10 \mathrm{~mL}$ of $\mathrm{HNO}_{3}$ and $25.0 \mathrm{~mL}$ of concentrated $\mathrm{H}_{2} \mathrm{SO}_{4}$. The mixture was stirred at $60^{\circ} \mathrm{C}$ for $1 \mathrm{~h}$ in a water bath. Subsequently, the reaction mixture was placed in an ice bath. The nitrated resin was filtered, washed several times with water until free of acid and then treated with a mixture of $40 \mathrm{~g}$ of $\mathrm{SnCl}_{2}, 45.0 \mathrm{~mL}$ of concentrated $\mathrm{HCl}$ and $50.0 \mathrm{~mL}$ of ethanol. The mixture was then refluxed for 12 hours at $90{ }^{\circ} \mathrm{C}$. The precipitated solid was filtered and washed with water and $\mathrm{NaOH}$ $2.0 \mathrm{~mol} \mathrm{~L}^{-1}$. The amino-resin was first washed with $\mathrm{HCl} 2.0 \mathrm{~mol} \mathrm{~L}^{-1}$, and finally with distilled water to remove $\mathrm{HCl}$ excess. The resin was suspended in a mixture of $\mathrm{HCl} 1.0 \mathrm{~mol} \mathrm{~L}^{-1}$ and $\mathrm{NaNO}_{2} 1.0 \mathrm{~mol} \mathrm{~L}^{-1}$ in an ice bath. The diazotized resin was filtered, washed with cold water and placed in reaction with 3,4-dihydroxybenzoic acid, DHB (3.3 $\mathrm{g}$ in 250 $\mathrm{mL}$ of a $10 \% \mathrm{NaOH}$ solution $\mathrm{w} / \mathrm{v}$ ) between $0-3{ }^{\circ} \mathrm{C}$ for $24 \mathrm{~h}$. The resulting brown-colored resin was filtered, washed with water and air dried.

A cylindrical polyvinyl minicolumn $(3.50 \mathrm{~cm}$ $\times 4.0 \mathrm{~mm}$ i.d.) was packed with $100 \mathrm{mg}$ of DHBXAD-2 resin. Polyurethane foams were fixed at both ends to avoid material loss. The minicolumn was first washed with a nitric acid solution $2.0 \mathrm{~mol}$ $\mathrm{L}^{-1}$, and then with deionized water.

\section{PREPARATION OF THE SAMPLES}

The sediment samples were collected along Contas River which passes through the urban area of the city of Jequié - Bahia. They were collected using a cylindrical sampler made of PVC at a distance of $2 \mathrm{~m}$ from the river bank. The samples were placed in plastic bags, transported to the laboratory and stove-dried at $60{ }^{\circ} \mathrm{C}$ for $24 \mathrm{~h}$. Afterwards, the samples were comminuted in mortar and pestle and sieved through a 200 micron sieve. Subsequently $0.15 \mathrm{~g}$ of the samples were digested by adding 10 $\mathrm{mL}$ of aqua regia (three portions of concentrated hydrochloric acid and one of nitric acid moiety).

Cigarette samples were acquired from local commerce. About $0.15 \mathrm{~g}$ of this sample were digested by adding $25 \mathrm{~mL}$ of concentrated nitric acid. The mixture was maintained overnight (at least 12 hours). The next day $5 \mathrm{~mL}$ of $\mathrm{H}_{2} \mathrm{O}_{2} 30 \%$ $(\mathrm{v} / \mathrm{v})$ was added and the digestion was processed.

Food samples were colected from local market from Jequié city, bringed to laboratory, washed, dry 
at $60{ }^{\circ} \mathrm{C}$ in stove in a period of $24 \mathrm{~h}$, grinding in knife mill and passing through a sieve $(200 \mu \mathrm{m})$. After this, $0.4 \mathrm{~g}$ of the sample was digested by adding $10 \mathrm{~mL}$ of $\mathrm{HNO}_{3}$ and $4.0 \mathrm{~mL}$ of $\mathrm{H}_{2} \mathrm{O}_{2}$.

All the samples were digested in digester block at $110{ }^{\circ} \mathrm{C}$ for 4 hours. The solutions $\mathrm{pH}$ was adjusted with sodium hydroxide solution and an appropriate buffer. The mixture was diluted to 50 $\mathrm{mL}$ with deionized water. These solutions were analyzed immediately after preparation.

\section{MULTIVARIATE OPTIMIZATION}

The procedure was optimized using a modified simplex algorithm. The variables that affected significantly the preconcentration process are $\mathrm{pH}$ and sampling flow rate. These parameters were chosen according to work described in the literature and previous experiments which indicated these variables to be those that most affect the system's performance.

The possible movements for the modified simplex (reflection, expansion, contraction and contraction with changing of direction) are shown in Figure 2. In this case, it is a two dimensions simplex, comprising three vertices, an equilateral triangle. The initial simplex is represented by the triangle $\mathrm{BNW}$. The vertex $\mathrm{B}$ represents the better answer, $\mathrm{N}$ is the second better answer and $\mathrm{W}$ is the worst answer. The BNR simplex is obtained by the initial simplex reflection movement. The BNS simplex is obtained from the BNR simplex expansion movement. The BNU simplex is obtained by a contraction and the BNT simplex is obtained through a contraction with change of direction (Bezerra et al. 2016).

The values of the initial experiment, which formed the vertices of an equilateral triangle of the first simplex and its variation steps, were chosen in order to achieve the optimal values quickly. The initial simplex was moved in the experimental space toward the optimal response region by applying the movement rules established for the modified

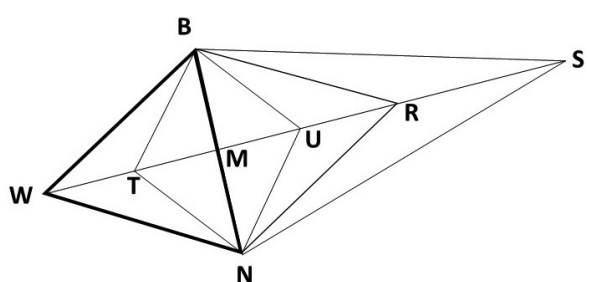

Figure 2 - Possible movements for the modified simplex.

simplex. In all optimization process, it was used 50 $\mathrm{mL}$ of a $50 \mu \mathrm{g} \mathrm{mL}^{-1}$ cadmium solution. Experimental data obtained from simplex optimization were processed using the Excel ${ }^{\circledR}$ software.

\section{RESULTS AND DISCUSSION}

\section{OPTIMIZATION PROCEDURE}

The variables ( $\mathrm{pH}$ and sampling flow rate) were selected because they had a greater effect on the preconcentration system for cadmium determination and need be optimized. For two variables, we have, thus, a simplex in two dimensions represented by an equilateral triangle. Hence, the initial simplex consists of three vertices (one more than the number of variables) which were established by the initial values assigned to each variable and the definition of the step size (maximum value allowed for variation of a factor during the first simplex construction) of each variable. In this work, the initial value was stablished as $12.3 \mathrm{~mL} \mathrm{~min}^{-1}$ and 5.0 , with step variations of $1.2 \mathrm{~mL} \mathrm{~min}^{-1}$ and 0.92 for sample flow rate and $\mathrm{pH}$, respectively.

Applying then the optimization rules of the modified simplex, the initial simplex was moved towards the optimal response region, as shown in Table I. Thus, the vertex corresponding to the worst response was rejected and replaced by its reflection. Then, we performed expansion, contraction or contraction movements with change of direction, depending on the response, generating consequently a new vertex and forming a new simplex.

Figures 3 (a) and (b) show the values of the two parameters regarding the number of vertices. 
TABLE I

Values obtained through the simplex optimization.

\begin{tabular}{ccccc}
\hline Experiment & Vertex & *Flow rate & pH & $\begin{array}{c}\text { Analytical signal } \\
\text { (Absorbance) }\end{array}$ \\
\hline 01 & I & 12.3 & 5.0 & 0.016 \\
02 & I & 13.5 & 5.0 & 0.007 \\
03 & I & 12.9 & 5.8 & 0.009 \\
04 & R & 11.7 & 5.8 & 0.011 \\
05 & E & 10.8 & 6.3 & 0.011 \\
06 & R & 11.4 & 7.2 & 0.013 \\
07 & E & 10.9 & 8.3 & 0.080 \\
$\mathbf{0 8}$ & R & $\mathbf{8 . 8}$ & $\mathbf{8 . 7}$ & $\mathbf{0 . 1 0 2}$ \\
09 & E & 6.8 & 10.1 & 0.070 \\
10 & R & 9.0 & 10.7 & 0.080 \\
11 & C & 9.4 & 9.6 & 0.070 \\
12 & R & 10.0 & 10.0 & 0.060 \\
13 & C & 8.2 & 9.6 & 0.070 \\
\hline
\end{tabular}

*Sample flow rate $\left(\mathrm{mL} \mathrm{min}^{-1}\right) ; \mathrm{I}=$ initial simplex; $\mathrm{R}=$ reflection of the vertex with the worst response; $\mathrm{E}=$ expansion of the vertex with the best response; $\mathrm{R} 8=$ reflection of vertex $8 ; \mathrm{C}=$ contraction.

The sample flow rate showed a tendency to better responses with lower values as the vertex number increases. However, a significant variation is observed, thus the sample flow rate does not exert a great influence in the proposed preconcentration system. The $\mathrm{pH}$ tends to higher values when the vertex is moving to the optimal region, indicating that this variable has great influence in the preconcentration system, with a greater influence than the sampling flow rate.

The experiments were then performed using the established vertices until the progress of the analytic signal was no longer observed, as shown in Figure 4. As can be seen, the highest absorbance value was obtained in vertex 8 . Hence, the best one for the studied variables corresponds to the experimental conditions specified by this vertex (flow rate of $8.8 \mathrm{~mL} \mathrm{~min}^{-1}$ and $\mathrm{pH} 8.7$ ).

\section{ANALYTICAL CHARACTERISTICS}

The analytical characteristics of the proposed procedure were assessed after optimization. The regression curve obtained from the preconcentration process was as follows: $\mathrm{Abs}=0.0046 \mathrm{C}_{\mathrm{Cd}}\left(\mu \mathrm{g} \mathrm{L}^{-1}\right)+$ $0.0091, \mathrm{R}=0.9930$ for cadmium standard solutions with concentrations between 10.0 and $70.0 \mu \mathrm{g} \mathrm{L} \mathrm{L}^{-1}$. For curve without preconcentration, this equation was obtained: $\mathrm{Abs}=0.0003 \mathrm{C}_{\mathrm{Cd}}\left(\mu \mathrm{g} \mathrm{L}{ }^{-1}\right)+0.0017$, $\mathrm{R}=0.9987$, for cadmium standard solutions with concentrations between 200 and $1000 \mu \mathrm{g} \mathrm{L}^{-1}$. This equation was obtained under optimal spectrometer conditions.

The limits of detection (LOD) and quantification (LOQ) are defined as LOD $=3 \mathrm{~s} / \mathrm{a}$ and LOQ $=10 \mathrm{~s} / \mathrm{a}$, respectively, where a is the slope of the analytical curve and $\mathrm{s}$ is the standard deviation of ten consecutive measurements of the signal of the analytical blank. For $50.0 \mathrm{~mL}$ of the sample solution used in the preconcentration process, we obtained a LOD of de $0.49 \mu \mathrm{g} \mathrm{L}^{-1}$ and a LOQ of 1.65 $\mu \mathrm{g} \mathrm{L}^{-1}$. The limits of detection and quantification expressed in $\mu \mathrm{g} \mathrm{g}^{-1}$ for a sample mass of $0.15 \mathrm{~g}$ of sendiment and cigarette and $0.4 \mathrm{~g}$ of food sample are shown in Table II. The precision (repeatability), expressed in terms of relative standard deviation was $5.9 \%\left(n=10,10 \mu \mathrm{g} \mathrm{L}^{-1}\right)$. The enrichment factor (EF) calculated as the ratio between the angular coefficients of the analytical curves with preconcentration and without preconcentration was 15.3 times. 
a)

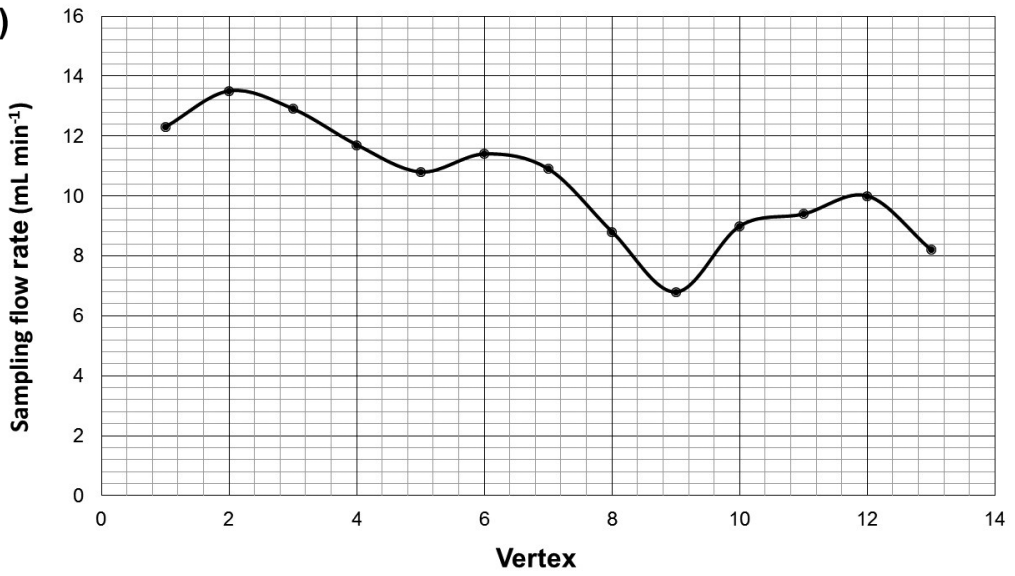

b)

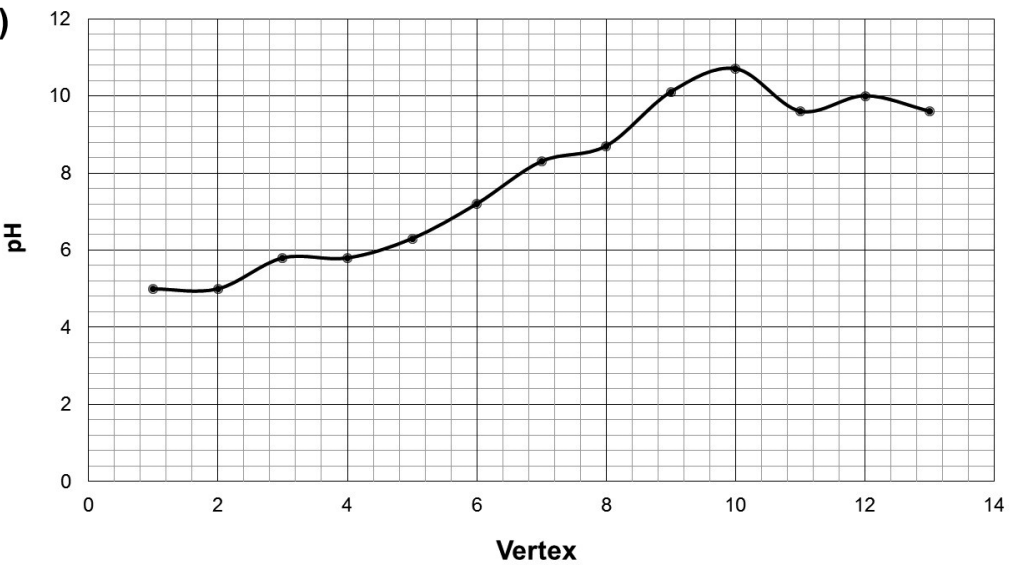

Figure 3 - Evolution of the variables values with the displacement of the triangle defined by the simplex method. (a) sampling flow rate, (b) $\mathrm{pH}$.

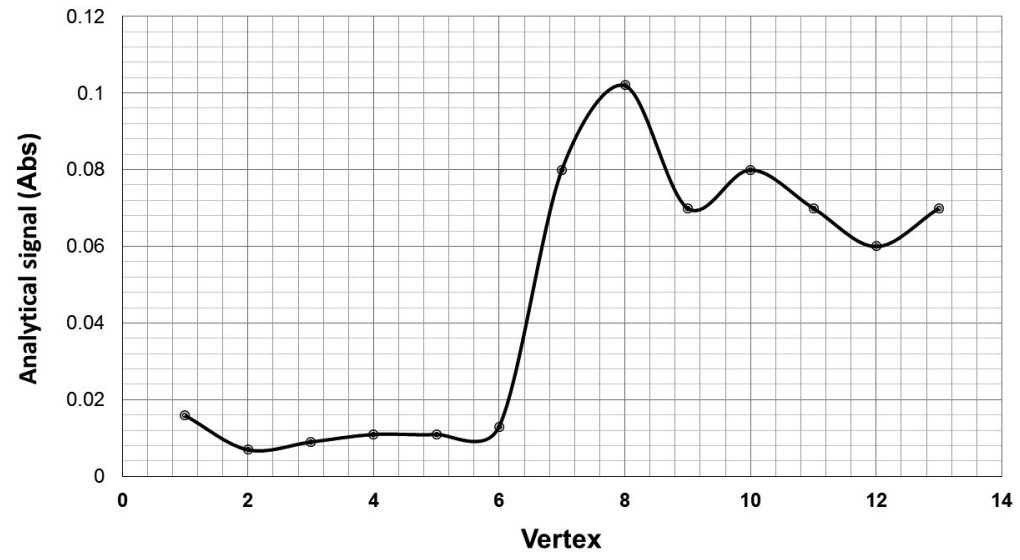

Figure 4 - Evolution of the analytical signal in diverse conditions for each vertex of the triangle defined by the simplex method 
TABLE II

Limits of detection and quantification based on sample mass calculated for samples of sediments, cigarettes and food.

\begin{tabular}{ccc}
\hline Sample (mass) & LOD $\left(\mu \mathbf{g ~ g}^{-1}\right)$ & LOQ $\left(\boldsymbol{\mu g ~ ~ ^ { - 1 } )}\right.$ \\
\hline Sediments $(0.15 \mathrm{~g})$ & 0.16 & 0.55 \\
Cigarettes $(0.15 \mathrm{~g})$ & 0.050 & 0.16 \\
Food $(0.4 \mathrm{~g})$ & 0.061 & 0.21 \\
\hline
\end{tabular}

A comparison between analytical parameters obtained by the proposed method with that paramenter from other work carried out for cadmium determination are presented in Table III. It is concluded that, the developed method presents analytical characteristics compatible with the described by the literature.

\section{ACCURACY AND APPLICATION}

The accuracy of the procedure was assessed by certified reference material analysis, of estuary sediment (NIST 1646-1). The value found through the proposed method was $156.0 \pm 5.0 \mu \mathrm{g} \mathrm{kg}^{-1}$ and the certificate value was $148.0 \mu \mathrm{g} \mathrm{kg}^{-1}$. To compare the obtained results using the developed methodology to the certified value we used Student's t-test, and there were no significant differences between the value found by the proposed method and the certified one, at a 95\% confidence level. The proposed procedure was applied to the determination of $\mathrm{Cd}$ in samples of sediments, cigarettes and food. The results are given respectively in Table IV.

\section{CONCLUSION}

The use of a modified simplex algorithm allowed a fast and efficient optimization of a preconcentration

\section{TABLE III}

Comparison among the performance of the proposed method and some methods from literature that also use solidphase extraction for cadmium determination by FAAS.

\begin{tabular}{crrrcc}
\hline $\begin{array}{c}\text { SV } \\
(\mathbf{m L})\end{array}$ & $\mathbf{E F}$ & $\begin{array}{c}\text { LOD } \\
\left(\boldsymbol{\mu g} \mathbf{~ L}^{-1}\right)\end{array}$ & $\begin{array}{r}\text { RSD } \\
(\boldsymbol{\%})\end{array}$ & Samples & References \\
\hline 10 & 39 & 0.15 & 3.15 & Waters and soils & (Jalbani and Soylak 2014) \\
10 & 27.6 & 0.3 & - & Mineral waters and certified reference materials & (Karadas et al. 2013) \\
20 & 18.4 & 0.19 & - & Cigarettes, waters, lobster pancreas and fish liver & (Costa et al. 2011) \\
25 & 250 & 0.13 & $<4$ & Foods and waters & (Daşbaşi et al. 2015) \\
50 & 100 & 1.19 & 1.40 & Waters & (Orala et al. 2011) \\
50 & 15.3 & 0.49 & 5.9 & Sediments, cigarettes and foods & This work \\
\hline
\end{tabular}

Notes: SV, sample volume; EF: enrichment factor; LOD: limite of detection; RSD: relative standard deviation.

TABLE IV

Determination $(\mathrm{N}=3)$ of cadmium in samples of sediments, cigarettes and foods.

\begin{tabular}{ccc}
\hline Kind of sample & Sample & Concentration $\left(\mu \mathrm{g} \mathrm{g}^{-1}\right)$ \\
\hline Sediment & 1 & $1.90 \pm 0.02$ \\
Sediment & 2 & $1.73 \pm 0.03$ \\
Sediment & 3 & $1.84 \pm 0.03$ \\
Cigarette & 1 & $0.193 \pm 0.05$ \\
Cigarette & 2 & $0.085 \pm 0.06$ \\
Food & Coriander & $0.33 \pm 0.05$ \\
Food & lettuce & $0.12 \pm 0.05$ \\
\hline
\end{tabular}


system proposed for cadmium determination. Conducting a small number of experiments was necessary to achieve the optimal simplex response region, thus reducing analysis time and reagents consumption. It also enabled a more precise location of the optimum point. The developed method presented analytical characteristics (limits of detection, limit of quantification, precision and accuracy) suitable for cadmium determination in samples of sediments, cigarettes and food. The amount of cadmium found in all the studied samples is within the limits established by the legislation.

\section{ACKNOWLEDGMENTS}

The authors acknowledge the financial support provided by the Fundação de Amparo à Pesquisa do Estado da Bahia (FAPESB) and the Conselho Nacional de Desenvolvimento Científico e Tecnológico (CNPq)

\section{RESUMO}

Um simplex de algoritmo modificado foi utilizado na otimização de um sistema de pré-concentração para determinação de cádmio em amostras de sedimentos, cigarros e alimentos por espectrometria de absorção atômica com chama. O sistema de pré-concentração baseia-se na sorção do cádmio em uma minicoluna recheada com uma resina de Amberlite XAD-2 funcionalizada com o ácido 3,4-dihidrixibenzóico (DHB). As variáveis otimizadas foram $\mathrm{pH}$ e vazão da amostragem. As condições ótimas encontradas para estas variáveis foram, respectivamente: 8,7 e $8,8 \mathrm{~mL}$ $\mathrm{min}^{-1}$. O sistema desenvolvido apresentou fator de préconcentração de 15,3 vezes, limite de deteç̧ão de 0,49 $\mu \mathrm{g} \mathrm{L}^{-1}$, limite de quantificação de $1,65 \mu \mathrm{g} \mathrm{L}^{-1}$ e precisão expressa pelo desvio padrão relativo $(\% \mathrm{RSD}, \mathrm{n}=10)$ de 5,9. A exatidão do método foi determinada através da aplicação do sistema desenvolvido em material de referência certificado de sedimento de estuário (NIST 1646-1). As concentrações de cádmio encontradas nas amostras de sedimentos variaram entre 1,73 e 1,90 $\mu \mathrm{g} \mathrm{g}^{-1}$. Nas amostras de cigarros os resultados obtidos foram 0,085 e $0,193 \mu \mathrm{g} \mathrm{g}^{-1}$, e nas amostras de alimentos (coentro e alface) as concentrações encontradas deste metal foram, respectivamente, 0,33 e $0,12 \mu \mathrm{g} \mathrm{g}^{-1}$.

Palavras-chave: otimização simplex, pré-concentração, cádmio, sedimentos, cigarros, alimentos.

\section{REFERENCES}

ABDUlLiN IF, TUROVA EN AND BUDNIKOV GK. 2000 Determination of copper and cadmium by atomic absorption spectrometry with electrochemical and sorption preconcentration. J Anal Chem 55: 567-569.

AMORIM FAC AND FERREIRA SLC. 2005. Determination of cadmium and lead in table salt by sequential multi-element flame atomic absorption spectrometry. Talanta 65: 960964.

ANTHEMIDIS AN AND IOANNOU KG. 2010. Development of a sequential injection dispersive liquid-liquid microextraction system for electrothermal atomic absorption spectrometry by using a hydrophobic sorbent material: determination of lead and cadmium in natural waters. Anal Chim Acta 668(1): 35-40.

Bezerra MA, SAntos QO, SAntos AG, Novaes CG, FERREIRA SLC AND SOUZA VS. 2016. Simplex optimization: A tutorial approach and recent applications in analytical chemistry. Microchem J 124: 45-54.

CAMEL V. 2003. Solid-phase extraction of trace elements. Spectrochim. Acta B 58: 1177-1233.

COSTA LM, RIBEIRO ES, SEGATElli MG, NASCIMENTO DR, OLIVEIRA FM AND TARLEY CRT. 2011. Adsorption studies of $\mathrm{Cd}(\mathrm{II})$ onto $\mathrm{Al}_{2} \mathrm{O}_{3} / \mathrm{Nb}_{2} \mathrm{O}_{5}$ mixed oxide dispersed on silica matrix and its on-line preconcentration and determination by flame atomic absorption spectrometry. Spectrochim Acta 66: 329-337.

DAŞBAŞI T, SAÇMACI Ş, ÜLGEN A AND KARTAL Ş. 2015. A solid-phase extraction procedure for the determination of $\mathrm{Cd}(\mathrm{II})$ and $\mathrm{Pb}$ (II) ions in food and water samples by flame atomic absorption spectrometry. Food Chem 174: 591-596.

DiAS LF, MIRANDA GR, SAINT'PIERRE TD, MAIA SM, FRESCURA VLA AND CURTIUS AJ. 2005. Method development for the determination of cadmium, copper, lead, selenium and thallium in sediments by slurry sampling electrothermal vaporization inductively coupled plasma mass spectrometry and isotopic dilution calibration. Spectrochim Acta B 60(1): 117-124.

DÖNER G AND EGE A. 2005. Determination of copper, cadmium and lead in seawater and mineral water by flame atomic absorption spectrometry after coprecipitation with aluminum hydroxide. Anal Chim Acta 547: 14-17.

ESCALEIRA L, SANTELLI R, OLIVEIRA E, CARVALHO MFB AND BEZERRA MA. 2009. Preconcentration procedure for determining trace amounts of $\mathrm{Ni}, \mathrm{Cd}, \mathrm{Pb}$ and $\mathrm{Cu}$ in highsalinity waters after cloud-point extraction. Int J Environ Anal Chem 89: 515-527. 
FERreira SLC, ANDRAdE JB, KORN MGA, PEREIRA MG, LEMOS VA, SANTOS WNL, ROdRIGUES FM, SOUZA AS, FERREIRA HS AND SILVA EGP. 2007. Review of procedures involving separation and preconcentration for the determination of cadmium using spectrometric techniques. J Hazard Mater 145: 358-367.

GIESY JP AND HOKE RA. 1989. Freshwater sediment toxicity bioassessment: rationale for species selection and test design. J Great Lakes Res 15: 539-569.

JALBANI N AND SOYLAK M. 2014. Ligand less surfactant mediated solid-phase extraction combined with $\mathrm{Fe}_{3} \mathrm{O}_{4}$ nano-particle for the preconcentration and determination of cadmium and lead in water and soil samples followed by flame atomic absorption spectrometry: Multivariate strategy. Ecotoxicol Environ Saf 102: 174-178.

Julshamn K, MaAge A, Norli HS, Grobecker KH, JORHEM L, FECHER P AND DOWELL D. 2013. Determination of arsenic, cadmium, mercury, and lead in foods by pressure digestion and inductively coupled plasma/ mass spectrometry: first action 2013.06. J AOAC Int 96(5) 1101-1102.

KARADAS C, TURHAN O AND KARA D. 2013. Synthesis and application of a new functionalized resin for use in an online, solid-phase extraction system for the determination of trace elements in waters and reference cereal materials by flame atomic absorption spectrometry. Food Chem 141: 655-661.

LEMOS VA, BALIZA PX, YAMAKI RT, ROCHA ME AND ALVES APO. 2003. Synthesis and application of a functionalized resin in on-line system for copper preconcentration and determination in foods by flame atomic absorption spectrometry. Talanta 68: 675-682.

LEMOS VA AND CARVALHO AL. 2010. Determination of cadmium and lead in human biological samples by spectrometric techniques: a review. Environ Monit Assess 171: 255-265.

Lemos VA, GAMA EM AND LIMA AS. 2006. On-Line Preconcentration and Determination of Cadmium, Cobalt and Nickel in Food Samples by Flame Atomic Absorption Spectrometry Using a New Functionalized Resin. Microchim Acta 153: 179-186.

Lemos VA, Novaes CG, VIEIRA DR AND LimA AS. 2008. Flow injection preconcentration system using a new functionalized resin for determination of cadmium and nickel in tobacco samples. J Hazard Mater 155: 128-134.

NELDER JA AND MEAD R. 1965. A simplex method for function minimization. Comput J 7: 308-312.

NetO BB, BRUnS RE AND SCARMINIO IS. 1995. Planejamento e Otimização de Experimentos: pesquisa e desenvolvimento na ciência e na indústria, $2^{\mathrm{a}}$ ed., Unicamp, 350 p.

Novaes CG, SANTOS JS, FERREIRA SLC AND LEMOS VA. 2010. Synthesis of a new solid-phase extractor and its application to preconcentration and determination of lead in water samples. J AOAC Int 93(5): 1609-1615.

OJEDA CB, ROJAS FS AND PAVÓN JMC. 2010. Preconcentration of cadmium in Environmental Samples by Cloud Point Extraction and Determination by FAAS. AJAC 1: 127-134.

ORALA EV, DOLAK, I, TEMELB H AND ZIYADANOGULLARI B. 2011. Preconcentration and determination of copper and cadmium ions with 1,6-bis(2-carboxy aldehyde phenoxy) butane functionalized Amberlite XAD-16 by flame atomic absorption spectrometry. J Hazard Mater 186: 724-730.

PAUla CER, CALDAS LFS, BRUM DM AND CASSElla RJ. 2012. Development of an ultrasonic slurry sampling method for the determination of $\mathrm{Cu}$ and $\mathrm{Mn}$ in antibiotic tablets by electrothermal atomic absorption spectrometry. J Pharm Biomed Anal 66: 197-203.

Rodrigues DV, CASTRO JT AND LEMOS VA. 2011. Determination of Lead and Manganese in Biological Samples and Sediment Using Slurry Sampling and Flame Atomic Absorption Spectrometry. J AOAC Int 94(2): 645649.

SHOKROLlaHi A, JOYBAR S, HAGHIGHI HE, NIKNAM K AND NIKNAM E. 2013. Application of cloud point preconcentration and flame atomic absorption spectrometry for the determination of cadmium and zinc ions in urine, blood serum and water samples. Quím Nova 36(3): 368-374.

SHOKROLlAHI A, JOYBAR S, HAGHIGHI HE, NiKNAM K, NiKNAM E, MENDIL D AND TUZEN M. 2011. Assessment of trace elements in animal tissues from Turkey. Asian J Chem 23: 4851-4854.

SILVA EL AND ROLDAN PS. 2009. Simultaneous flow injection preconcentration of lead and cadmium using cloud point extraction and determination by atomic absorption spectrometry. J Hazard Mater 161: 142-147. 